\title{
SPONSORSHIP EVALUATION IN SOUTH AFRICA
}

\author{
ADELE D BERNDT (RAU) \& CL KOEKEMOER (AAA School of Advertising)
}

Sponsorships are regarded as a marketing communications activity. This is seem as an investment made by an organisation that need to be evaluated in terms of its return and contribution. Sport sponsorships have increased in South Africa since readmittance to the international sports arena. There are various objectives for sponsorships. The identification of these objectives is important for the evaluation of sponsorships. The articles proposes some guidelines for the evaluation of sponsorships.

\section{BACKGROUND}

Sponsorship of events, sport and broadcasts has increased in prominence in the past ten years, largely due to an increase in sponsorship opportunities since the release of Mandela and South Africa's re-entry into the global sporting arena. This has demanded the investment of increasing amounts of money in this aspect of marketing communication. In 1987, the amount of money invested in sponsorship was R85 million (Koenderman 1988:117). The figures for 1996 indicate that approximately R650 million was invested in all types of sponsorships, an increase of $665 \%$ over this period (Koenderman 1997:75). The estimated investment in sponsorship in 1999 amounted to approximately R1 049 million (Koenderman 2000:97). This reflects growth of $25 \%$ to $30 \%$ per annum in sponsorship investment, which is larger than that found in other marketing disciplines (Koenderman 1997:75). Approximately the same amount of money is spent on radio advertising and on sponsorships in this country annually, indicating the relative importance and widespread use of sponsorship by organisations in South Africa (Koenderman 1997:75).

\section{THE TERM "SPONSORSHIP”}

A sponsorship is the marketing communication activity whereby an organisation contractually makes a financial or material investment in an individual, activity or broadcast in order to achieve predetermined objectives for the organisation among the members of the organisation's target market (Abratt et al. 1987:300; Association of Marketers 1997:1).

This definition acknowledges sponsorships as a marketing communication activity which seeks to achieve marketing and marketing communication objectives for the organisation. This is in contrast to other definitions, which refer to it as being either a corporate or a marketing activity. Sponsorship is always an investment made by the organisation, although it may be of either a financial or a material nature.

\section{THE PROBLEM}

Any financial investment is constantly evaluated by the organisation to determine its performance with regard to its return and the contribution made to the organisation. Should the investment not be performing adequately (as required by the organisation), the investment will be changed or halted. As sponsorship is a form of investment, it needs to be evaluated like any other financial investment, more particularly in terms of its required performance. The sponsorship is required to yield a commercial benefit for the sponsoring organisation, and evaluating the benefit is important to its continued use by the organisation (Meenaghan 1983:9).

Sponsorship and the evaluation of sponsorship performance presents an opportunity within South Africa as more sponsorships are being entered into and the amount of money being invested keeps increasing. Organisations are convinced of the importance of sponsorship evaluation, yet find it difficult to decide how the sponsorship should be evaluated and what methods should be used to do so. The methods selected must suit the sponsorship and the objectives set for it. 


\section{SPONSORSHIP OBJECTIVES AND SPONSORSHIP EVALUATION TOOLS}

\section{Sponsorship objectives}

Various sponsorship objectives have been identified in the literature (Meenaghan, Pope, Thwaites). The identification of sponsorship objectives forms a crucial part of the decisions relating to sponsorship evaluation. Without a clear objective for the sponsorship, its evaluation becomes difficult.

The main sponsorship objectives are summarised in table 1 below.

Table 1: A summary of the main sponsorship objectives

\begin{tabular}{|l|l|}
\hline Objective & Description \\
\hline Corporate & $\begin{array}{l}\text { Using the sponsorship to change the attitude, image and awareness } \\
\text { among those inside and outside the organisation toward the } \\
\text { organisation as a whole }\end{array}$ \\
\hline Product & $\begin{array}{l}\text { Using sponsorships to affect the image, awareness, market share } \\
\text { and sales of the organisation's product }\end{array}$ \\
\hline Sales & Increase in the number of units sold over time \\
\hline Media & $\begin{array}{l}\text { Obtaining coverage and publicity for the organisation in a variety of } \\
\text { media }\end{array}$ \\
\hline Entertainment & $\begin{array}{l}\text { Hospitality afforded to clients, dealers and staff to reward, thank and } \\
\text { motivate them }\end{array}$ \\
\hline Personal & Selected by the CEO of an organisation through personal interest \\
\hline Communication & $\begin{array}{l}\text { Using the sponsorship to affect the image of the organisation and } \\
\text { awareness among the target market }\end{array}$ \\
\hline Other & $\begin{array}{l}\text { Dealer response; number of spectators; motivation of sales } \\
\text { representatives; global awareness }\end{array}$ \\
\hline
\end{tabular}

Sources: Abratt et al. 1987:306; Crimmins \& Horn 1996:11; Meenaghan 1983:17-24; Meenaghan 1991:10; Parker 1991:22

\section{Sponsorship evaluation}

The nature of each objective determines the sponsorship evaluation tools used to evaluate the sponsorship investment. Such an evaluation will indicate whether the sponsorship was successful with respect to the nature and size of the return, if any, accruing to the organisation. Various methods of sponsorship evaluation have been identified. These include advertising-based, sales-based and sponsorship-specific methods. The table 2 summarises the more important sponsorship evaluation tools identified in the literature.

\section{THE STUDY}

The overall objective of the study was to examine the evaluation of sponsorship in South Africa. Due to the relationship between evaluation and the pre-determined sponsorship objectives, this could only be done by determining what objectives, if any, have been set by organisations involved in sponsorship.

Primary research was conducted among organisations who were sponsors of events, individuals and broadcasts in South Africa. These sponsors were asked to indicate the sponsorship objectives and evaluation methods used to evaluate a sponsorship as well as the extent to which they believed that a long-term sales effect can be determined. The research universe comprised 121 past and present 
sponsors of events and broadcasts. The instrument was a self-completion questionnaire, and use was made of both personal and mail delivery. A response rate of $42 \%$ was obtained.

Table 2: The more important evaluation tools for sponsorships

\begin{tabular}{|c|c|c|}
\hline Evaluation method & Aspect measured & Evaluation tool \\
\hline Advertising-based methods & $\begin{array}{l}\text { Awareness; } \\
\text { media coverage; } \\
\text { exposure; } \\
\text { attitudes }\end{array}$ & $\begin{array}{l}\text { Awareness measurement; } \\
\text { Exposure measurement; } \\
\text { Audience/viewership size; } \\
\text { Liking/ favourability rating; } \\
\text { Consumer surveys; } \\
\text { Attitude surveys; } \\
\text { Tracking studies; } \\
\text { Consumer surveys; } \\
\text { Sort and count/coupons; } \\
\text { Opinion measurement }\end{array}$ \\
\hline Sales-based measurements & Sales effects & $\begin{array}{l}\text { Direct sales measurement; } \\
\text { Econometric analysis; } \\
\text { Financial statements; } \\
\text { Cost-benefit analysis; } \\
\text { Market share analysis; } \\
\text { Generating sales leads; } \\
\text { Controlled experimentation; } \\
\text { Return On Investment; } \\
\text { Investment techniques }\end{array}$ \\
\hline Sponsorship-specific methods & Sponsorship-specific effects & $\begin{array}{l}\text { Persuasion impact equation; } \\
\text { Sponsorship effect model; } \\
\text { Hospitality evaluation; } \\
\text { Dealer response; } \\
\text { Sponsorship effect model; } \\
\text { Spindex method; } \\
\text { Pepsi and Gillette methods }\end{array}$ \\
\hline Other methods & & Gut feel/subjective evaluation \\
\hline
\end{tabular}

Sources: Abratt \& Grobler 1989:353; Crimmins \& Horn 1996:13; Howard \& Crompton 1995:364; Hunter 2000:16; Koekemoer 1989:321; Meenaghan 1983:47-50; Parker 1991:22.

\section{RESEARCH RESULTS}

\section{Findings regarding sponsorship in South Africa}

Sport is the area of sponsorship activity for $52,3 \%$ of respondents, with the sponsorship of art and education some way behind in their use.

Three out of ten respondents $(31,9 \%)$ indicated that they invested less than half a million rand (R500 000) in sponsorships, reflecting the widespread use of sponsorships at lower levels of financial investment.

Sponsorship support (leverage) of $80 \%$ to $100 \%$ of the direct sponsorship investment is recommended in the literature. It was found that no additional sponsorship support was given by $13,7 \%$ of respondents and a further $29,4 \%$ of respondents made provision for less than $20 \%$ of the original sponsorship investment in the form of leverage. In total, $43,1 \%$ of respondents invest less than $20 \%$ of the sponsorship investment in the form of leverage. 


\section{Reasons for the use of sponsorships and the benefits accruing from their use}

Attaining brand/product awareness was identified as the key role of sponsorships. Social responsibility and corporate image building are also considered to be key to sponsorship involvement. Reasons not indicated as reasons for involvement in sponsorships are corporate and client hospitality, dealer relations and the personal interest of the CEO.

Media coverage/publicity was identified by nearly three out of ten respondents ( 41 respondents or $28,3 \%$ ) as the desired benefit accruing from the use of sponsorships. Corporate/product image was indicated by nearly two out of ten respondents (24 respondents or $16,6 \%$ ) as being a specific benefit of their sponsorship involvement. Sales benefits were identified by slightly more than one in ten respondents $(15,2 \%)$.

\section{Findings concerning sponsorship objectives}

The following objectives were identified as being set by sponsors:

- Brand awareness objectives had the highest frequency among the respondents, with more than four out of ten respondents (41 respondents or $45,6 \%$ ) indicating this objective for their sponsorships.

- Publicity/media mention objectives were set by 39 respondents $(43,3 \%)$.

- Social responsibility (community relations) objectives were set by 37 respondents $(41,1 \%)$.

- Corporate image objectives were set by 36 respondents $(40,0 \%)$.

All these objectives have, as a primary focus, communication with the target market.

\section{Sales objectives as sponsorship objectives}

Three out of ten respondents $(30,0 \%)$ stated that they set a sales objective for their sponsorships. A sales objective was set by $43,6 \%$ of respondents involved in sport, contrasted with $31,3 \%$ of those involved in arts sponsorships.

\section{Findings concerning sponsorship evaluation tools}

All sponsorship evaluation tools identified in the literature were presented to the respondents. The respondents were asked to indicate which tools they use in the different areas of sponsorship in which they were involved. The respondents were free to indicate as many of the evaluation tools as desired.

Advertising-based sponsorship evaluation methods are methods that evaluate the communication effectiveness of sponsorships. Examples of these methods include awareness and attitude surveys. The advertising-based methods, namely media exposure $(46,7 \%)$, awareness surveys $(41,1 \%)$ and attitude surveys $(39,4 \%)$ were the sponsorship evaluation methods with the highest frequencies.

Sales-based evaluation methods included cost-benefit analysis $(23,3 \%)$, return on investment $(23,3 \%)$, and market share analysis $(21,1 \%)$. These tools did not appear to receive the same levels of support as the advertising-based methods.

Sponsorship-specific methods such as the persuasion impact equation had the following overall frequencies of use among respondents - dealer-response (16,7\%), survey among guests $(10,0 \%)$ and persuasion impact equation $(5,6 \%)$. These constitute some of the lowest frequencies identified.

Approximately one in five respondents (21 respondents or $23,3 \%$ ) said their organisation used subjective evaluation as a sponsorship evaluation tool.

\section{Specific sponsorship evaluation tools used}

The following sponsorship evaluation tools were identified by respondents: 
- Media exposure as a sponsorship evaluation tool is recorded by $46,7 \%$;

- Awareness surveys $(41,1 \%)$;

- Attitude surveys $(34,4 \%)$;

- Audience/viewership size, 27 respondents or $30,0 \%$, of whom 18 used it in the evaluation of sport sponsorships;

- Subjective evaluation $(23,3 \%)$. The use of subjective evaluation is greater among those involved in art sponsorships rather than sport sponsorships.

The use of direct sales measurement, although relatively limited, is more common in the evaluation of sport sponsorships $(83,3 \%)$, rather than arts sponsorships $(8,3 \%)$.

\section{Evaluation tools in the various areas of sponsorship activity}

Different tools can be identified in the evaluation of sponsorship activity.

- Arts sponsorships: Tools used to evaluate arts sponsorships mainly included media exposure, awareness surveys and attitude surveys. The use of subjective evaluation was also identified in this area of sponsorship evaluation.

- Sport sponsorships: The evaluation tools with the highest frequencies are media exposure, awareness surveys and attitude surveys. In addition, the frequent use of audience/viewership size, return on investment $(\mathrm{ROI})$ and cost-benefit analysis to evaluate sponsorships is evident here. A reason for the use of these additional techniques could be the size of the investment in sport sponsorship, as well as the television coverage that sport receives.

- Education sponsorships: Media exposure and awareness surveys were indicated as being used to evaluate these sponsorships. The use of subjective evaluation as an evaluation tool was also indicated by respondents.

\section{RECOMMENDATIONS}

From the responses received, it is possible to propose guidelines for the evaluation of sponsorships, based on the objectives organisations set for the specific sponsorships in which they are involved. These guidelines are summarised in table 3 below. 
Table 3: $\quad$ Specific sponsorship objectives and sponsorship evaluation tools

\begin{tabular}{|c|c|c|c|}
\hline Objective & Evaluation tool & $\begin{array}{l}\text { Situationl } \\
\text { circumstances }\end{array}$ & $\begin{array}{l}\text { Proposed evaluation } \\
\text { tools }\end{array}$ \\
\hline Corporate & $\begin{array}{l}\text { Media exposure; } \\
\text { awareness and } \\
\text { attitude surveys; }\end{array}$ & $\begin{array}{l}\text { Changing situation in the } \\
\text { organisation about which the } \\
\text { target market must know or to } \\
\text { improve image of the } \\
\text { organisation }\end{array}$ & $\begin{array}{l}\text { Advertising-based } \\
\text { methods; } \\
\text { sponsorship-specific } \\
\text { methods }\end{array}$ \\
\hline Product & $\begin{array}{l}\text { Awareness } \\
\text { surveys; direct } \\
\text { sales effects }\end{array}$ & $\begin{array}{l}\text { Stable/declining awareness of } \\
\text { product; product launch }\end{array}$ & $\begin{array}{l}\text { Advertising-based } \\
\text { methods; } \\
\text { sales-based methods }\end{array}$ \\
\hline Sales & $\begin{array}{l}\text { Direct sales; } \\
\text { market share; ROI }\end{array}$ & $\begin{array}{l}\text { Use of promotions together with } \\
\text { sales to monitor sponsorship } \\
\text { effects }\end{array}$ & Sales-based methods \\
\hline Media & $\begin{array}{l}\text { Exposure; } \\
\text { awareness }\end{array}$ & & $\begin{array}{l}\text { Advertising-based } \\
\text { methods }\end{array}$ \\
\hline Entertainment & $\begin{array}{l}\text { Hospitality } \\
\text { measures } \\
\text { Consumer surveys; } \\
\text { Media exposure; }\end{array}$ & $\begin{array}{l}\text { Morale and image benefits are } \\
\text { desired }\end{array}$ & $\begin{array}{l}\text { Dealer response } \\
\text { techniques; } \\
\text { hospitality evaluation; } \\
\text { sponsorship-specific } \\
\text { methods }\end{array}$ \\
\hline Personal & $\begin{array}{l}\text { Subjective } \\
\text { evaluation }\end{array}$ & & Subjective evaluation \\
\hline Communication & $\begin{array}{l}\text { Media exposure; } \\
\text { awareness surveys }\end{array}$ & $\begin{array}{l}\text { To change existing awareness } \\
\text { and perceptions among the } \\
\text { target market }\end{array}$ & $\begin{array}{l}\text { Advertising-based } \\
\text { methods }\end{array}$ \\
\hline \multirow[t]{4}{*}{ Other } & Dealer support & $\begin{array}{l}\text { product-dependent i.e. not used } \\
\text { by all sponsors; } \\
\text { useful when attempting to } \\
\text { gain/improve shelf space }\end{array}$ & $\begin{array}{l}\text { Dealer response; } \\
\text { techniques; } \\
\text { sponsorship-specific } \\
\text { methods }\end{array}$ \\
\hline & $\begin{array}{l}\text { Audience/ } \\
\text { viewership size }\end{array}$ & $\begin{array}{l}\text { Specific to broadcast and print } \\
\text { sponsorships }\end{array}$ & $\begin{array}{l}\text { Audience measurement } \\
\text { techniques }\end{array}$ \\
\hline & Staff motivation & $\begin{array}{l}\text { Internal to the organisation; name } \\
\text { change or image and perception } \\
\text { changes needed }\end{array}$ & $\begin{array}{l}\text { Traditional staff } \\
\text { motivation measures }\end{array}$ \\
\hline & Global awareness & International expansion & $\begin{array}{l}\text { Advertising-based } \\
\text { methods. }\end{array}$ \\
\hline
\end{tabular}




\section{BIBLIOGRAPHY}

ABRATT R, CLAYTON, BC \& PITT LF. 1987. Corporate objectives in sports sponsorship. International Journal of Advertising, 6:299-311.

ABRATT R \& GROBLER PS. 1989. The evaluation of sports sponsorships. International Journal of Advertising, 8:351-362.

ASSOCIATION OF MARKETERS. 1997. Sponsorship guidelines.

CRIMMINS J \& HORN M. 1996. Sponsorship : From management ego trip to marketing success. Journal of Advertising Research, 36(4):11-21.

HOWARD DR \& CROMPTON JL. 1995. Financing Sport. Morgantown : Fitness Information Technology.

HUNTER C. 2000. Spindex puts a different spin on the value of sponsorship. Business Report: 16 September.

KOEKEMOER CL. ed. 1989. Marketing communications management - a South African perspective. Butterworths : Durban.

KOENDERMAN T. 1997. Ambushers cut off at the pass. Financial Mail, 146 (1), August 1.

KOENDERMAN T. 1988. Media \& Marketing focus. Finance Week, 38:117-118. November 17 - 23.

KOENDERMAN T. 2000. Sponsors are queuing up for winners. Adfocus 2000. (Supplement to Financial Mail) :96-100, May 19.

MEENAGHAN JA. 1983. Commercial Sponsorship. European Journal of Marketing, 17(1):5-70.

MEENAGHAN T. 1991. Sponsorship - Legitimising the Medium. European Journal of Marketing, 25(11):5-10.

PARKER K. 1991. Sponsorship : the research contribution. European Journal of Marketing, 25(11):22-30. 